\title{
Evidence for sedimenting particles as the origin of the microbial community in a coastal marine sediment
}

\author{
James A. Novitsky \\ Department of Biology, Dalhousie University, Halifax, Nova Scotia, Canada B3H 4J1
}

\begin{abstract}
The origin of the microbial community in a coastal marine sediment was investigated by examining the physical, chemical, and microbial characteristics of the sedimenting particles in Halifax Harbor, Canada. Particles were collected using particle interceptor traps placed on the sediment surface. The measured rate of particle accumulation compared to the sediment accumulation rate indicates that over $85 \%$ of the dry weight of the particles is removed (including resuspension) or solubilized before deposition as sediment. Active decomposition is facilitated by the large microbial community present. The particles are heavily colonized by both bacteria $\left(10^{9} \mathrm{~g}^{-1}\right)$ and protozoa $\left(10^{6} \mathrm{~g}^{-1}\right)$ before they reach the sediment such that the microbial communities of the sinking particles and sediment-water interface are nearly indistinguishable. The particles and sediment are also similar with respect to community growth rates and carbon, nitrogen, and ATP content. Artificial sediment cores inserted into the sediment and left in place for 1 yr were colonized only to a depth of $4 \mathrm{~cm}$. The data indicate that an extensive microbial community is already established on particles before they become sediment and that in situ sediment colonization is not necessary for the establishment of the sediment microbial community.
\end{abstract}

\section{INTRODUCTION}

It is a well established fact that the surface layers of both marine and freshwater sediments are habitats for large microbial communities. Indeed, populations in excess of $10^{10}$ bacteria per $g$ of sediment have been reported. Several aspects of these communities have been investigated: distribution (Schroder \& Van Es 1980, Rublee 1982), metabolic activity (Novitsky 1983a), biomass (Craven et al. 1986, Novitsky \& Karl 1986), enumeration of metabolically-active cells (Douglas et al. 1987), growth rate (Novitsky 1987, Karl \& Novitsky 1988), productivity (Newell \& Fallon 1982, Burns et al. 1984), degradation of microbial biomass (Novitsky 1986), and the relationship between microbiology and sediment chemistry (Meyer-Reil et al. 1980). However, to date, no study has addressed the question of the origin of the sediment microbial community. Is it a specific community that develops in or on the sediment, or is it the accumulation of microbes that have sedimented from the water column either as free cells or as cells attached to particles? Is the sediment merely a depository or graveyard for pelagic microbes? In a previous publication (Novitsky 1986) I examined the fate, but not the origin, of microbial biomass in marine sediments. That study indicated that dead microbial biomass is quickly degraded, suggesting that the large sediment community is alive (but not necessarily metabolically active). Furthermore, an additional study (Novitsky 1987) has shown that most of the microbial community is not growing. If this microbial community originates in, and actively colonizes the sediment as it is deposited, nearly $100 \%$ of the population would be expected to be actively growing. Putting these points and observations together, it seems reasonable to hypothesize that the sediment microbial community does not originate in the sediment but is deposited from some other source. After sedimentation, the sediment environment then selects the microbes best suited for growth under the present conditions. The nongrowing portion, active prior to sedimentation, now remains dormant (possibly moribund) until conditions again become favorable for growth. The present study was designed to test these hypotheses. 


\section{MATERIALS AND METHODS}

Sample collection. All samples were collected from the Eastern Passage area of Halifax Harbor, Canada, a site used in previous studies (Novitsky 1983a,b, 1987). All samples were collected by hand by SCUBA divers. Water samples were collected in clean, 11 plastic bottles. Sediment samples were collected in plastic core tubes carefully inserted into the sediment (Novitsky 1983b). Sediment-water interface samples were removed from intact, undisturbed cores by careful aspiration using a large syringe fitted with a $16 \mathrm{~g}$ teflon canula (Novitsky 1983b). Sedimented particles were collected in particle interceptor traps based on a design described by Knauer et al. (1979). Each trap was composed of a plastic tube $6 \times 60 \mathrm{~cm}$ closed at the bottom end with a rubber stopper and fitted on the top end with a collar containing a nylon screen (square, $1.96 \mathrm{~mm}$ openings). Eight traps were fitted into a weighted, sturdy plastic box that could be set on the sediment surface with the traps in a vertical position. Before deployment, each trap was filled with the appropriate solution and capped. Once deployed and stable, SCUBA divers would carefully remove the caps from the tubes to begin collection. Traps were routinely deployed for a period of 2 wk except for growth rate and DNA synthesis determinations. These 'live' collections were for the minimum period needed to collect an adequate amount of material, 4 to $6 \mathrm{~d}$. For recovery, divers would gently descend, recap the tubes, and attach a recovery line to the box. For recovery of fresh material, traps were filled with filtered (Millipore, 0.45 um membrane) seawater. For the collection and preservation of cells for direct microscopic counts, traps were filled with $1.5 \mathrm{l}$ of a high density formalin solution containing: $40 \mathrm{~g}$ artificial sea-salts (Rila Marine Mix, Rila Marine Products, Teaneck, NJ) and $2 \%$ (final concentration) formalin in $1 \mathrm{l}$ seawater. For the in situ extraction of ATP, traps were filled with $1.5 \mathrm{l}$ of a high density acid solution containing: $132 \mathrm{~g} \mathrm{NaCl}, 51 \mathrm{ml}$ concentrated phosphoric acid, and distilled water to make 1.51. The high density solutions were filtered (Millipore, $0.45 \mu \mathrm{m}$ membrane) and added to the traps. The remaining trap volume was carefully filled with filtered seawater.

Analytical procedures. For ATP extractions from fresh sediment trap material and interface samples, quintuplicate, $1 \mathrm{ml}$ slurry samples were injected into $5 \mathrm{ml}$ boiling, $60 \mathrm{mM}$ phosphate buffer and allowed to boil for $5 \mathrm{~min}$. For water samples, duplicate, $250 \mathrm{ml}$ samples were passed through Whatman GF/F filters which, after filtration was complete, were immediately placed into boiling phosphate buffer. For in situextracted ATP from sediment traps, ten $50 \mathrm{ml}$ subsamples from each trap were processed as described previ- ously (Novitsky \& Karl 1985). After extraction, for all samples, ATP was measured using the firefly bioluminescence reaction (Karl \& Craven 1980). To correct for apparent and real losses of extractable ATP, internal standards were added to quintuplicate samples from all sites and processed in an identical manner.

The organic carbon content and the carbon/nitrogen ratio of the sediment trap material and the sedimentwater interface were determined by filtering $10 \mathrm{ml}$ of a sediment slurry onto silver filters $(0.8 \mu \mathrm{m}$ Hytrex membranes, Osmonics, Inc., Minnetonka, MN). After drying the filters were exposed to fuming acid and then analyzed for carbon and nitrogen using a carbonhydrogen-nitrogen analyzer (Hewlett-Packard 185B).

DNA synthesis rates were measured using ${ }^{3} \mathrm{H}$ adenine as described by Karl \& Novitsky (1988) and Novitsky \& Karl (1986). Interface or sediment trap slurries used in this study contained ca 5 to $10 \mathrm{mg}$ dry wt sediment mi

Samples for dissolved oxygen determinations were removed from the sediment traps immediately upon recovery. Samples were removed from various depths within the traps using a siphon of small-bore plastic tubing. Oxygen was determined by the Winkler method as modified and described by Strickland \& Parsons (1972).

Direct microscopic counts. Interface and fresh sediment trap samples were fixed with $2 \%$ formalin. All samples were handled and mixed very gently to protect the protozoa. Five to $10 \mathrm{ml}$ portions of fixed samples or appropriate dilutions were filtered with minimum vacuum onto prestained (overnight in a 1:15000 solution of Sudan black B in $50 \%$ ethanol) $0.2 \mu \mathrm{m}$ Nuclepore filters and washed once with $2 \mathrm{ml}$ Trizma $\mathrm{HCl}$ (Sigma Chemical Co.) buffer $(0.1 \mathrm{M}, \mathrm{pH} 4)$. The cells were stained with $2 \mathrm{ml}$ of primulin stain $(25 \mathrm{mg}$ primulin in $100 \mathrm{ml}$ Trizma buffer) for $5 \mathrm{~min}$ followed by a $2 \mathrm{ml}$ Trizma buffer wash. Air-dried filters were mounted in immersion oil and examined with a Wild-Leitz epifluorescence microscope. For direct counts, at least 40 fields from one edge, through the center, to the opposite edge of the filter were counted. Cells with characteristic protozoan morphology without red-orange chlorophyll autofluorescence were counted as protozoa. Cells showing autofluorescence, regardless of morphology, were counted as autotrophs. After the protozod were enumerated the samples were homogenized in a blender $(3 \times 30 \mathrm{~s})$ to increase the precision of the bacteria counts. Bacteria were enumerated after staining with acridine orange as previously described (Novitsky 1983a).

Growth rate determinations. Two methods were used to determine the growth rate of the microbial community. For both methods interface or sediment trap slurries were prepared containing ca 5 to $10 \mathrm{mg}$ 
dry wt sediment $\mathrm{ml}^{-1}$. Adenine nucleotide (AN) pool turnover rate measurements were performed according to the procedure of Karl \& Bossard (1985) using ${ }^{3} \mathrm{H}$ adenine (Karl et al. 1987). Growth rates were calculated from the AN pool turnover times assuming that the pool turns over $40 \times$ generation $^{-1}$ (Karl \& Bossard 1985). Growth rates were also determined using ${ }^{3} \mathrm{H}$ adenine and the pulse labeling technique of LaRock et al. (1988). For interface and sediment trap material ${ }^{3} \mathrm{H}$ adenine pulses of 105 min followed by acid precipitation of nucleic acids and isolation and purification of ${ }^{3} \mathrm{H}$-DNA (Novitsky \& Karl 1986) were carried out at $1 \mathrm{~h}$ intervals over a $6 \mathrm{~h}$ period. For water samples, ${ }^{3} \mathrm{H}$ adenine pulses of 30 min were carried out at $1 \mathrm{~h}$ intervals over a $6 \mathrm{~h}$ period. After each pulse, triplicate $100 \mathrm{ml}$ aliquots were filtered through Whatman GF/F filters and the nucleic acids were precipitated with cold, $10 \%$ trichloroacetic acid. After precipitation, the filters were washed with $95 \%$ ethanol $(3 \times 10 \mathrm{ml})$ and dried. The radioactivity on the filters was determined by liquid scintillation counting.

Biomass carbon production. DNA synthesis rates were measured using ${ }^{3} \mathrm{H}$-adenine as described by Novitsky \& Karl (1986) using the ATP integrated specific activity method of Winn \& Karl (1984). Carbon production was extrapolated from rates of DNA synthesis by assuming that 1 pmol of DNA is equivalent to $1236 \mathrm{pg}$ of DNA produced and that DNA accounts for $2 \%$ of cell carbon.

Artificial sediment studies. Small glass beads with a nominal diameter of $5 \mu \mathrm{m}$ (size MS-XLX, Waldron Co., Inc., North Haven, CT) were used as an artificial sediment medium to study sediment colonization. Prior to deployment, the beads were soaked for $2 \mathrm{~h}$ in detergent, washed $10 \times$ with distilled water, soaked overnight in $10 \% \mathrm{HCl}$, washed $10 \times$ with distilled water, and then washed twice with filtered seawater. The slurry was then added to $6 \times 29 \mathrm{~cm}$ plastic tubes fitted with $44 \mu \mathrm{m}$ mesh screens near the bottom to retain the beads. Slurry was added and allowed to settle until a column of ca

Table 1. Chemical comparison of sedimented particles and the sediment-water interface of Halifax Harbor, Canada

\begin{tabular}{|c|c|c|}
\hline Parameter & Particles & Interface \\
\hline \multicolumn{3}{|l|}{ ATP [ug $\left.(g d r y w t)^{-1}\right]$} \\
\hline Extracted upon recovery ${ }^{a}$ & $10.74(n=18)$ & $25.50(n=6)$ \\
\hline Extracted in situ & $24.66(n=6)$ & \\
\hline Organic carbon (\% dry wt) & 1.49 & 1.76 \\
\hline Percent living carbon ${ }^{\mathrm{b}}$ & $41.65^{\mathrm{c}}$ & 36.13 \\
\hline $\mathrm{C}: \mathrm{N}$ (molar ratio) & 6.08 & 5.69 \\
\hline \multicolumn{3}{|l|}{ a Deployments of 12 to $14 \mathrm{~d}$} \\
\hline \multicolumn{3}{|c|}{ b $($ ATP $\times 250$ /organic carbon $) \times 100$} \\
\hline \multicolumn{3}{|c|}{ In situ-extracted ATP used in calculation } \\
\hline
\end{tabular}

$20 \mathrm{~cm}$ was added. The bottom of each tube was capped with a rubber stopper, the head space filled with filtered seawater, and the top capped with a rubber stopper. Eight such tubes were lowered in a box to a depth of $10 \mathrm{~m}$ at which time divers removed the top and bottom stoppers. The tubes were taken to the bottom and inserted vertically into the sediment so that the artificial and natural sediment surfaces were approximately even. For recovery, a diver would recap the tube, remove it from the sediment, restopper the bottom, and bring it to the surface. In the laboratory, any collected natural sediment was carefully removed from the surface of the artificial sediment before the artificial sediment was extruded from the tube. Horizons, 0.5 to $1 \mathrm{~cm}$, were cut from the sediment core, placed in a beaker and mixed thoroughly. Quintuplicate subsamples were then assayed for ATP as follows: ca $1 \mathrm{~cm}^{3}$ was loaded into a plastic, cut-off syringe barrel and then injected into $5 \mathrm{ml}$ of boiling phosphate buffer to extract ATP. After the ATP analysis, the tubes containing the sediment and buffer were centrifuged and the remaining buffer was aspirated. The tube and sediment were dried at $80^{\circ} \mathrm{C}$ and weighed. The sediment was then discarded and the tubes reweighed. The dry weight of the sediment sample was then calculated by difference.

\section{RESULTS AND DISCUSSION}

The sedimentation of particles was measured over a 6 mo period from May to October, 1988. The traps in this study were placed directly on the sediment surface to collect particles as close (temporally and spatially) as possible to the sediment-water interface. While this positioning increased the possibility of collecting resuspended material, the design of the traps and comparison of inter-and intratrap data lead me to conclude that this was not a significant problem in the relatively short collection periods used in this study. The particulate matter collected in the sediment traps ranged from 26.2 (May) to $55.2 \mathrm{~g}$ dry wt $\mathrm{m}^{-2} \mathrm{~d}^{-1}$ (July). Due to weather conditions it was impossible to deploy the traps during

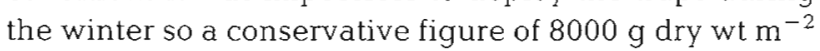
$\mathrm{yr}^{-1}$ was estimated. The dry weight of $1 \mathrm{~m}^{2}$ of the top $1 \mathrm{~cm}$ of sediment at this location was determined to be $4530 \mathrm{~g}$ while the sediment accumulation rate at this site was previously measured at $0.25 \mathrm{~cm}(1133 \mathrm{~g}) \mathrm{yr}^{-1}$ (Kepkay \& Novitsky 1980). Using these estimates and measurements, over $85 \%$ of the sedimenting material is solubilized, mineralized, resuspended, or otherwise removed before final sediment deposition. There is no doubt that the microbial community is responsible for mineralization of some of the sedimenting carbon; however, since the organic carbon represents only $1.5 \%$ of the dry weight of the particles (Table 1) it is 
Regardless of minor differences in overall community growth rates, both the particles and the interface are heavily colonized by both bacteria and protozoa (Table 3). By the time particles reach the bottom, the sizes of the microbial communities of the particles and the sediment-water interface are virtually identical. With $10^{10}$ bacteria and $10^{6}$ protozoa per g, particles appear to be an excellent habitat for microbial growth [although autotrophs are present, their low relative numbers and the fact that light intensity at the sediment-water interface is $<1.0 \%$ of the intensity at the water surface (Novitsky 1983b), their growth and impact on this environment would be minimal]. As already discussed, community doubling times measured for the microbial community associated with the particles are no greater than $40 \mathrm{~h}$ (a relatively fast growth rate at $2^{\circ} \mathrm{C}$ ), comparable to doubling times measured for interface communities (Table 2). The biomass carbon production was higher for the interface than for the particles on both an absolute and per unit (ATP) biomass basis. The reason(s) for this is unclear especially in light of the similar growth rates. One possibility is that the cells in the interface are larger and hence produce more biomass with the same doubling time. While possible, this is doubtful since it was impossible to show a statistical difference in cell size between the two communities. In addition, both habitats have similar ATP and organic carbon content as well as similar C: $\mathrm{N}$ ratios (Table 1).

The results of this study that indicate the sedimenting particles are a good habitat for microbial growth contradict the conclusion reached by Karl et al. (1988) for sinking particles in the north Pacific. They based their conclusion, in part, on the limited utilization of particulate organic carbon (POC) and particulate organic nitrogen (PON) by live traps compared to formalin-killed controls and the difference between ATP extracted in situ and ATP extracted upon recovery (shipboard ATP). Since the shipboard/in situ ratio was low (usually $<0.25$ ), they concluded that the microbial community of the particles was in a state of decline and therefore that the particles were a poor habitat for microbial colonization. I have also measured a low recovery/in situ ATP ratio (0.44, Table 1) and agree that the microbes in the traps are dying; however, I propose a hypothesis for the cause of this death that was not discussed by Karl et al. (1988). The in situextracted ATP content of the particles in this study is virtually the same as that measured for the interface. Since the particles were collected just above the sediment surface, the interface should represent aged' particles similar to those caught in the traps. Why is the ATP content of these 'aged' particles different from the ATP content of the interface? A possibility is that during the period of particle collection [12 to $14 \mathrm{~d}$, this study; 6 to 33 d, Karl et al. (1988)] the microbial communities in the traps utilize the oxygen present and quickly create anaerobic conditions, thus committing microbial suicide. Since the traps are specifically designed to prevent mixing of the contents with the surrounding seawater, oxygen could only be replenished by diffusion. To test this hypothesis I measured dissolved oxygen in a recovered trap that had been deployed for $14 \mathrm{~d}$. Oxygen measured in the water at the mouth of the trap was $9.7 \mathrm{mg} \mathrm{l}^{-1}$; in the middle (30 $\mathrm{cm}$ from the top) $6.7 \mathrm{mg} \mathrm{l}^{-1}$; and only $5.2 \mathrm{mg} \mathrm{l}^{-1}$ near the bottom $(50 \mathrm{~cm}$ from the top). In addition, although they didn't report oxygen concentrations, Knauer et al. (1979) reported the presence of $\mathrm{H}_{2} \mathrm{~S}$ in unpreserved trap material. Certainly these depleted oxygen conditions must have an effect on the microbes. Accordingly, the more organic material collected and the longer the deployment, the greater depletion of oxygen that will occur Although Karl et al. (1988) deployed traps for up to $33 \mathrm{~d}$, the amount of POC collected per trap was low (ca 1 to $3 \mathrm{mg} C$ trap $^{-1}$ compared to $50 \mathrm{mg} \mathrm{C} \operatorname{trap}^{-1}$ in this study). With this small amount of carbon collected it seems unlikely that any corresponding small decrease in oxygen would cause a significant decrease in microbial biomass or activity. Nevertheless, until this hypothesis is examined more fully, care must be taken when interpreting results from these in situ 'live' incubations. If live material must be collected, the collection time should be as short as possible. Apparently unaffected by the in situ incubation is the total number of microbes trapped (Table 3). Although $50 \%$ of the biomass is dead, the

Table 3. Protozoa and bacteria (cells, per $g$ dry wt) associated with sedimenting particles and the sediment-water interface of Halifax Habor, Canada

\begin{tabular}{|c|c|c|c|c|c|c|}
\hline \multirow[t]{2}{*}{ Sample } & \multicolumn{6}{|c|}{ Cells (SD) } \\
\hline & $\mathrm{n}$ & Bacteria & n & Protozoa & $\mathrm{n}$ & Autotrophs \\
\hline $\begin{array}{l}\text { Sediment traps (samples fixed } \\
\text { after } 2 \text { wk deployment) }\end{array}$ & 18 & $1.67(1.52) \times 10^{10}$ & 18 & $4.74(1.89) \times 10^{6}$ & 3 & $3.05(0.87) \times 10^{5}$ \\
\hline $\begin{array}{l}\text { Sediment traps (samples fixed } \\
\text { in situ) }\end{array}$ & 11 & $2.68(2.73) \times 10^{10}$ & 11 & $3.72(1.49) \times 10^{6}$ & 4 & $6.41(1.27) \times 10^{5}$ \\
\hline Sediment-water interface & 8 & $1.49(0.35) \times 10^{10}$ & 8 & $4.30(2.94) \times 10^{6}$ & 4 & $5.06(3.58) \times 10^{5}$ \\
\hline
\end{tabular}


cells are still discernable by microscopic examination. These results notwithstanding, the use of a preservative as recommended by Knauer et al. (1979) is the best way to assure unchanged samples [for a comprehensive discussion of sediment trap material preservatives see Knauer et al. (1984)]. Although the conclusions of Karl et al. (1988) and this study are contradictory, they are not inconsistent. Combining the results from both studies a working hypothesis can be formed. Sinking particles in surface (depth $<50 \mathrm{~m}$ ), primarily coastal, waters are rich in labile organic matter and are good habitats for microbial growth and decomposition. In this situation, the microbial community associated with the particles plays an important role in the decomposition and flux of particulate organic matter (POM), and, as shown by this study, the diagenesis of coastal sediments. However, by the time particles reach deep (depth $>50 \mathrm{~m}$ ), open-ocean waters, labile POM has been removed and the sinking particles are no longer a good habitat for microbial colonization, resulting in a generally moribund community. In this situation, as suggested by Karl et al. (1988), microbial communities that are free-living in the water column or associated with non-sinking particles are more important in active remineralization of organic matter.

To examine the colonization of deeper horizons of sediment by particles sedimenting onto the sediment surface, artificial sediment cores were deployed for periods of up to $1 \mathrm{yr}$. After $3 \mathrm{mo}$, a visible interface

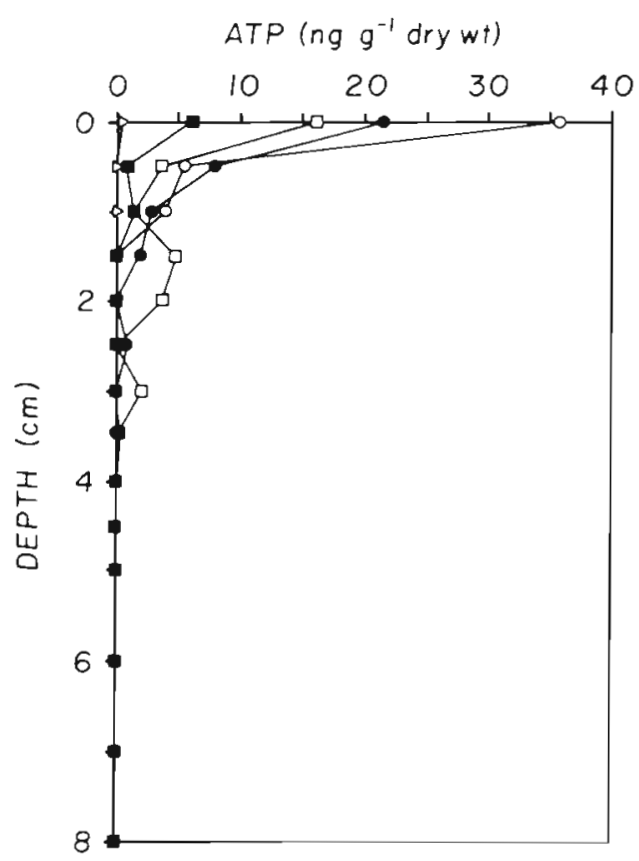

Fig. 1 Vertical profile of ATP biomass in artificial sediment cores deployed in Halıfax Harbor, Canada, sediment. Length of deployment: - (2 cores), 1 mo; $\square$ (2 cores), 3 mo; - (1 core), $1 \mathrm{yr}$ layer developed on top of the artificial sediment. This layer was identical in appearance and ATP content to interface material collected from real sediment cores. Below this interface, however, there was very little colonization of the artificial sediment. As can be seen in Fig. 1, ATP was detectable only in the top $4 \mathrm{~cm}$ and even in the 0 to $0.5 \mathrm{~cm}$ horizon, the ATP content of the artificial sediment was 2 orders of magnitude lower than would be found in normal surface sediment (Novitsky 1987). It is apparent that there is no extensive vertical movement either by the micro- or macro-biota in these sediments and that bioturbation is minimal. These observations suggest that the microbial community in the deeper horizons is initially deposited at the surface and becomes buried with continuous surface sediment accumulation. In addition, it is unlikely that deeper horizons are overturned to establish or reestablish surface sediment communities.

While it is impossible to rule out, at this time, the possibility of a specific microbial community developing in or on the sediment, the data suggest that the sediment community originates on sedimenting particles and is well established before the particles reach the sediment surface. Undoubtedly, some changes in the species composition of the population occurs, but the bulk of the microbial biomass sediments from the water column above. In addition, I have shown (Novitsky 1987) that most of the sediment microbial community is not actively growing. This conclusion raises the possibility that the nongrowing portion of the sediment community is composed of former particleassociated microbes that cannot grow in the sediment environment. Further studies are needed to identify the individual species comprising the water column, particle-associated and sediment-associated communities.

Acknowledgements. The author thanks J. Bugden, J. Cantley and $M$. Johnson for assistance in sampling and analysis. For expert diving and field services I acknowledge Dave Allen of the Richard W Welsford Research Group, Ltd. This research was supported by grant A-6548 from the National Research Council of Canada.

\section{LITERATURE CITED}

Burns, D., Andrews, C., Craven, D., Orrett, K., Pierce, B., Karl D. (1984). Microbial biomass, rates of DNA synthesis and estimated carbon production in Kaneohe Bay, Hawaii Bull. mar. Sci. 34: 346-357

Craven, D. B., Jahnke, R. A., Carlucci, A. F. (1986). Fine-scale vertical distributions of microbial biomass and activity in Californı Borderland sediments. Deep Sea Res. 33: 379-390

Douglas, D. J., Novitsky, J. A., Fournier, R. O. (1987). Microautoradiography-based enumeration of bacteria with estimates of thymidine-specific growth and production rates. Mar Ecol. Prog. Ser. 36: 91-99 
Karl, D. M., Bossard, P. (1985). Measurement and significance of ATP and adenine nucleotide pool turnover in microbial cells and environmental samples. J. microbiol. Meth. 3: 125-139

Karl, D. M., Craven, D. B. (1980). Effects of alkaline phosphatase activity on nucleotide measurements in aquatic microbial communities. Appl envirl Microbiol. 40: 549-561

Karl, D. M., Jones, D. R., Novitsky, J. A., Winn, C. D., Bossard, P. (1987). Specific growth rates of natural microbial communities measured by adenine nucleotide pool turnover. $J$. microbiol. Meth. 6: 221-235

Karl, D. M., Knauer, G. A., Martin, J. H. (1988). Downward flux of particulate organic matter in the ocean: A particle decomposition paradox. Nature, Lond. 332: 438-441

Karl, D. M., Novitsky, J. A. (1988). Dynamics of microbial growth in surface layers of a coastal marine sediment ecosystem. Mar. Ecol. Prog. Ser. 50: 169-176

Kepkay, P. E., Novitsky, J. A. (1980). Microbial control of organic carbon in marine sediments: coupled chemoautotrophy and heterotrophy. Mar. Biol. 55: 261-266

Knauer, G. A., Karl, D. M., Martin, J. H., Hunter, C. N. (1984). In situ effects of selected preservatives on total carbon, nitrogen and metals collected in sediment traps. J. mar. Res. 42: 445-462

Knauer, G. A., Martin, J. H., Bruland, K. W. (1979). Fluxes of particulate carbon, nitrogen, and phosphorus in the upper water column of the northeast Pacific. Deep Sea Res. 26A: $97-108$

LaRock, P. A., Schwarz, J. R., Hofer, K. G. (1988). Pulse labelling: A method for measuring microbial growth rates in the ocean. J. microbiol. Meth. 8: 281-298

Meyer-Reil, L.-A., Bolter, M., Dawson, R., Liebezeit, G., Szwerinski, H., Wolter, K. (1980). Interrelationships between microbiological and chemical parameters of sandy beach sediments, a summer aspect. Appl. envirl Microbiol. 39: 797-802

The article was presented by Dr S. Y Newell, Sapelo Island, Georgia, USA
Newell, S. Y., Fallon, R. D. (1982). Bacterial productivity in the water column and sediments of the Georgia (USA) coastal zone: estimates via direct counting and parallel measurement of thymidine incorporation. Microb. Ecol. 8: 33-46

Novitsky, J. A. (1983a). Heterotrophic activity throughout a vertical profile of seawater and sediment in Halifax Harbor, Canada. Appl. envirl Microbiol. 45: 1753-1760

Novitsky, J. A. (1983b). Microbial activity at the sedimentwater interface in Halifax Harbor, Canada. Appl. envir] Microbiol. 45: 1761-1766

Novitsky, J. A. (1986). Degradation of dead microbial biomass in a marine sediment. Appl envirl Microbiol. 52: 504-509

Novitsky, J. A. (1987). Microbial growth rates and biomass production in a marine sediment: evidence for a very active but mostly nongrowing community. Appl. envirl Microbiol. 53: 2368-2372

Novitsky, J. A., Karl, D. M. (1985). Influence of deep ocean sewage outfalls on the microbial activity of the surrounding sediment. Appl envirl Microbiol. 50: 1464-1473

Novitsky, J. A., Karl, D. M. (1986). Characterization of microbial activity in the surface layers of a coastal sub-tropical sediment. Mar. Ecol. Prog. Ser. 28: 49-55

Rublee, P. A. (1982). Bacterial and microbial distribution in estuarine sediments. In: Kennedy, V. (ed.) Estuarine comparisons. Academic Press, New York, p. 159-182

Schroder, H. G. J., Van Es, F. B. (1980). Distribution of bacteria in intertidal sediments of the Ems-Dollart estuary. Neth. $J$. Sea Res. 14: 268-287

Strickland, J. D. H., Parsons, T R. (1972). Determination of dissolved oxygen. In: A practical handbook of seawater analysis, Bulletin 167. Fish. Res. Bd Can., p. 21-26

Winn, C. D., Karl, D. M. (1984). Laboratory calibrations of the $\left[{ }^{3} \mathrm{H}\right]$ adenine technique for measuring rates of RNA and DNA synthesis in marine microorganisms. Appl. envirl Microbiol. 47: 835-842

Manuscript first received: July 31, 1989

Revised version accepted: November 1, 1989 